\title{
WHAT IS NEWTON'S LAW OF INERTIA?: THE USE OF QUESTIONS IN SCIENCE LECTURES
}

\author{
Akhyar Rido \\ Universitas Teknokrat Indonesia \\ email: akhyar_rido@teknokrat.ac.id
}

\begin{abstract}
An inability to recognize discourse structure is seen by applied linguists as one of the main problems of non-native speaker students in understanding science lectures in English. In this circumstance, the use of interactive discourse structure like questions is salient as it is likely to aid comprehension. The present study investigated the use of questions in science lectures in English in a university in Malaysia. By using conversation analysis (CA), a science lecturer was selected, video-recorded, and interviewed during two formal teaching hours. The findings show that the lecturer used a large quantity of display and referential questions. Display questions, comprising questions with ' $d o$ ', 'have' and to be 'is' and 'are,' were posed to encourage participation and check students' understanding toward the materials at hand. Meanwhile, referential questions, mostly started with 'what' or 'what do you think', 'how', 'when' and 'where', were employed to guide the students to understand science concept and stimulate critical thinking skills. Findings suggested that science lecturers use questions in various types and ways to foster learning.
\end{abstract}

Keywords: questions, types, functions, science lecture

\section{APAKAH HUKUM INERSIA NEWTON?: PENGGUNAAN PERTANYAAN DALAM PERKULIAHAN SAINS}

\begin{abstract}
Abstrak
Ketidakmampuan dalam mengenali struktur wacana dilihat oleh ahli linguistik terapan sebagai salah satu masalah utama mahasiswa bukan penutur asli dalam memahami perkuliahan sains dalam bahasa Inggris. Dalam keadaan ini, penggunaan struktur wacana interaktif seperti pertanyaan sangat penting karena akan membantu memahami perkuliahan. Penelitian ini mengkaji penggunaan pertanyaan dalam perkuliahan sains dalam bahasa Inggris di satu universitas di Malaysia. Dengan menggunakan analisis percakapan (CA), seorang dosen sains dipilih, direkam, dan diwawancara selama dua perkuliahan formal. Hasil penelitian menunjukkan bahwa dosen banyak menggunakan jenis pertanyaan display dan referensial. Pertanyaan display, yang terdiri dari pertanyaan dengan 'do', 'have', dan 'is' serta 'are, 'berfungsi untuk mendorong partisipasi dan memeriksa pemahaman mahasiswa terhadap materi yang disampaikan. Sementara itu, pertanyaan referensial, dimulai dengan 'what' atau 'what do you think', 'how', 'when' dan 'where',
\end{abstract}


digunakan untuk memandu mahasiswa memahami konsep sains dan merangsang keterampilan berpikir kritis. Oleh karena itu, hasil penelitian ini dapat menjadi pertimbangan para dosen sains untuk menggunakan berbagai jenis pertanyaan dengan berbagai cara untuk membantu memahami perkuliahan.

Kata Kunci: pertanyaan, jenis, fungsi, perkuliahan sains

\section{INTRODUCTION}

Currently, academic world is always associated with globalization which is characterized by linguistic and cultural diversities between lecturers and students (Camiciottoli, 2004). Globalization also demands academic institutions, especially universities, educate the students not only to be excellent in academic, but also in critical thinking and communication skills. The growing importance of these skills have created new challenges in university lectures. Athanasiadou (1991) and Comicciottoli (2004), suggest that interactive discourse structure like questions may have an important role in facilitating the acquisition of those skills and promoting engagement.

In the global context, a number of studies have investigated the implementation of questions in university settings (Morell, 2004, 2007; Olson and Huckin, 1990; Brock, 1986). Morell (2004, 2007) explored university lecture discourse and identified that display questions were present more frequently than referential questions. She found that the number of referential questions was correlated with the number of students' intervention. In terms of lenght and complexity, the students' responses toward reference questions was higher than display questions.
Therefore, it was concluded that referential questions improved students' engagement to the lectures. Examining questioning strategies in university engineering lectures in second language (L2), O1son and Huckin (1990) revealed that students have difficulties to understand the lectures. They found that the use of discussion technique through an exchange of a series of questions-answers facilitated negotiation of meaning which helped comprehension. In the same vein, Brock (1986) looked at how referential questions give an impact toward students' understanding of a classroom discourse. The study revealed that the lecturers utilized large number of open-referential and follow-up questions which improved criticial and logical thinking skills of students. In addition, possibility of losing face while responding with shorter answer was smaller than responding with a longer answer. Meanwhile, in the local context, Rido and Sari (2018) found that Indonesian and Malaysian teachers used questions over and over, approached students while questioning, and provided feedback using follow-up questions. These promoted learning and interaction.

According to Walsh (2011), Xuerong (2011), Athanasiadou (1991), questions may vary in their degree of textuality and 
generally consist of display, referential, rhetorical, and indirect questions. Distributing turn taking and encouraging participation are identified as the general functions of questioning while the specific functions are to better understand students' knowledge, elicit response, identify problems, and invite further discussions.

Shaping individuals' thinking through questions leads to create effective communication during workforce (North \& Worth, 2004; Riemer, 2007; Ihmeideh, Al-Omari, \& Al-Dababneh, 2010). These skills are required in professional practice especially in the science, engineering, and business contexts (Di Grapello, 2013; Di Grapello, Kruse, \& Tandon, 2011; Freihat, \& Al-Machzoomi, 2012; Hendarman, 2010; Riemer, 2007). To this end, an in situ research is on demand to find out the university science lecture context. Thus, this research tries to answer the question of what types and functions of questions are used in university science lecture?

\section{METHOD}

This qualitative research was aimed at reporting questions types and functions in a university science lecture in Malaysia. The party participated in this research was a professor/lecturer (L) with over two decades of experience teaching physics for undergraduate and postgraduate courses. Besides teaching, she involved in many research projects and attended seminars and workshops both as presenter and participant. In the running semester she taught physical mechanic course which was devided into some lectures. Each lecture was conduct- ed in a large lecture theatre and attended by appoximately 150 second year undergraduate students (S), comprising Malay, Indian, Chinese, Indonesian, and Arab students. Microphone helped the lecturer to deliver topics in front of the theatre. She sometimes monitored students' activities by walking around.

Meanwhile, the data were collected through video recording. Video-recording was used as it is the most suitable way to understand a complex interaction during the lectures. With the moving images, video recording is superior as the researcher gains a more complete sense of the participant, the settings that the participant are in and the role the participant play in the interactions and the types of activities the participant engage in the nature of these activities. Therefore, the disambiguate verbal message can be avoided using visual information which is narrowed down to possible number of accurate interpretation (Dufon, 2002; Wong \& Waring 2010).

In this study, the video recording process was directly conducted in the lecture theatre during the lectures. To capture the dominant view of lecture (two third angle of classroom), the video camera was put in the upper back corner. In total, two lecture sessions were successfully video-recorded. The first lecture (LE (1)) topic was 'forces' while the second topic (LE (2)) was 'centre of mass'. The first lecture lasted in 90 minutes while the second lecture lasted approximately $75 \mathrm{mi}$ nutes.

This research also employed an unstructured interview to help the researcher clarify the function of questions during the lectures from the participant's own 
perspective - emic view (Perakyla \& Ruusuvuvuori, 2013). Unstructured interviews were used as both the interviewer (the researcher) and the interviewee (the participant) agreed to do so. Unstructured interviews are characterized by open ended questions from which to follow-up during the interviews and they let also the interviewee give their own definition of situations (Creswell, 2007). The participant was informed about the research objectives and was asked for her consent. Her informed verbal consent was gained as she agreed to participate in this research (Curtis \& Curtis, 2013; Fontana and Frey, 2000).

Conversation analysis (CA) was used to analyze the data and consisted of fivestep analysis. First, all data obtained from video-recordings and interviews were organized and labelled in different folders in one database. Second, open-coding was done. Here, the data were studied carefully and the researcher was open to any possible category. Third, after opencoding the data, similar features might be obtained and emerging themes were also acquired. Fourth, sub-categories were classified by doing the focus-coding. Fifth, the triangulation toward the final emerging themes was presented and discussed.

\section{RESULTS AND DISCUSSION}

This research was aimed at investigating the use of questions in university science lectures, focusing on the types and functions. This section will reveal the results of the research. Data from videorecording will be presented and triangulated with interview data with the lecturer. The results from lecture one (LE (1)) will be firstly presented, followed by lecture two (LE (2)).

\section{Results}

Lecture 1

In LE (1), the results reveal that the lecture was dominated by the use of display and referential questions which have various functions. The questions functions were found not only in the form (what, when, how) but also coming in the sign of intonation raise at the end of the utterance. There are also polar questions (does, did, are, is), questions with 'modals' (can), and questions ended by a question tag (havent' you).

The lecture is started by the discussion about kinometics (lines 3-4). Although the main review is about motion, kinometics is also discussed by the lecturer. At the end of her statement, she poses a rhetorical question (lines 4-5). It introduces students to the topic about 'forces'. According to the lecturer, asking question in the beginning of the lecture functions to evoke students' background knowledge toward some concepts they learned before. This activity can be recognized from Excerpt 1 below.

\section{Excerpt 1: LE (1) \\ 3 L So far, you have been studying 4 about kinometics (.) basically they \\ $5 \quad$ are properties of motion, right?}

Concept introduction and relation of knowledge are explained right after reviewing previous lecture as stated in Excerpt 2. Question and answer helps lecturer to convince that the topic being discussed is not the new one by posing a dispay question ended by a question tag (lines 206-207), followed by a 'wh' refe- 
rential question (line 209), the lecturer reensures the students that they are going to deal with the same topic but with more comprehensive materials in the next levels. In fact, topic has been learnt in senior high school (lines 214-215) and preuniversity (line 217). Therefore, the lecturer asks the rhetorical question in lines 218-219. She, further, reviews the previous materials which relate to the current topic by asking questions (lines 222-225, 228-231, and 234-235). After that, Newton's law of motion is mentioned by the lecturer (lines 236-240). Here, the lecturer underlines that as science lecture always relates one key concept to another key concept, therefore, the questions posed are actually to ensure that the students can follow the lecture.

\begin{tabular}{|c|c|c|}
\hline \multicolumn{3}{|c|}{ Excerpt 2: LE (1) } \\
\hline 206 & $\mathrm{~L}$ & Forces. You have studied about forces \\
\hline 207 & & (/), haven't you? \\
\hline 208 & $\mathrm{~S}$ & (..) yes Mam. \\
\hline 209 & $\mathrm{~L}$ & when was it? \\
\hline 210 & & [moves back to ask students]. \\
\hline 211 & $\mathrm{~S}$ & (.5) form four (mumble) \\
\hline 212 & $\mathrm{~L}$ & yes? (/) \\
\hline 213 & S & form 4 \\
\hline 214 & $\mathrm{~L}$ & See?. Form 4. some more (/) stop \\
\hline 215 & & there(/) \\
\hline 216 & $\mathrm{~S}$ & (inaudible responses) \\
\hline 217 & $\mathrm{~L}$ & Form 5, Form 6. now,(.) you \\
\hline 218 & & haven't to be going deeper. Ok? If \\
\hline 219 & & $\begin{array}{l}\text { not, you have to repeat in form } 4 . \\
\text { right? }\end{array}$ \\
\hline 220 & $\mathrm{~S}$ & $\left(()^{\prime}\right)$ \\
\hline 221 & $\mathrm{~L}$ & (inaudible) So, Now, what is (/) \\
\hline 222 & & forces? (..)Can somebody tell me \\
\hline 233 & & what forces it? Now, when talking \\
\hline 224 & & about forces, what are the physics \\
\hline 225 & & topics we have to deal with? (.4) \\
\hline 226 & & Forces and (gap) \\
\hline 227 & & (.6) (silence) \\
\hline
\end{tabular}

228 L What are the topics (/) of physics

229 (...) that we are going to discuss,

230 when we have to discuss about forc-

231 es?

232 S (..) motion [echoing]

233 L (.hh) Mo::tion. Motion. Forces

234 and motion. What laws:: (/) was it

335 learnt in the past?

236 S Newton's law.

237 L Newton's law of (gap)?

238 S (.4) motion

239 L How many motions?

$240 \mathrm{~S} \quad(.5) 3$

The lecture continues by discussing the topic further. The following Excerpt 3 shows a long chunk of the lecture process. During the process, the lecturer asks six questions to three different students (lines 260-262, 270-271, 273, 276, 290, and 296-297); it contains three referential questions (lines 260-262, 273, and 296297). Identifying students' understanding about inertia is done by posing a referential question, 'What do you know about it?'. Furthermore, another personal referential question, 'How will you explain by not really?' shows reaction toward 'not really' (line 272) responding question about Newton's first law. Lastly, to provide feedback toward her question about Newtons' third law of motion (line 290) which is answered by the student (line 295), the lecturer asks the final referential question 'What does it mean by different direction?' (lines 296-297). The lecturer confirms that the basic principle of science lecture is understanding concept. Therefore, she tries to make the students further understand some concepts in physics (Newton's Law) through questions, indicating negotiation of meaning and confirmation checking. 
Excerpt 3: LE (1)

260 L Ok, Let me ask you a question.

261 Can you tell me what Newton's

262 law of inertia is? (.hh) what do

263 you know about it? [gives microphone to student]

264 S (.5) ok, principally the first law

265 of motion mentions that, an ob-

266 ject at rest will remain at rest,

267 unless an external force is ap-

268 plied (...) ehmm, towards that

269 object. (.3) So, (..) it is particularly (hh) about the inertia also.

270 L I see. (.4) So said first law of

271 motion refers to just (hh) a body at rest (I)?

272 S (.4) no, not really.

273 L How will you explain by not really?

274 S (laughter) the object still can be

$275 \quad$ (.3)moving also, can be still in motion.

276 L But (/). I sense a 'but' on it? (/)

277 S (.3) emm.. I'm not certain.

278 L So, you are in doubt. Ok. [gives

279 microphone to next student]

280 Come on. (.8) What is the second

281 law of motion? [laughs]

$282 \mathrm{~S}$ (.7) ((laughters and mumble)).

$283 \mathrm{~L}$ No, since this topic has been

284 studied before, I have to check

285 on you., (.4) so that, when lec-

286 turing I know you've known so far?

287 S The next force of motion is (.)

288 the next force of motion relates

289 to the mass of and the acceleration of the object.

$290 \mathrm{~L}$ (unclear) the third law of mo-

291 tion(/)? [searches the student to

292 participate in the discussion,

293 goes back to front centre] [gives

294 microphone to another student at first row]

295 S (.16) ahh, different direction.

296 L What does it mean by different

297 direction?

298 S different direction.
In continuing with her explanation during LE (1), in Excerpt 4 below, the concept of no-net forces is introduced (line 378). Right after introducing the concept, the lecturer asks the students about what no-net forces are. (lines 379 and 380). Not getting students' response (line 381), another question is posed (line 384), yet it makes no difference. After that, the no-net forces concept is elaborated through a question-answer process to the students. Hearing the students' answer, the lecturer ensures it by asking the next question (line 385) 'Are you sure they're just the same?'. However, the answer is found to be overused, and she clarifies that it is not correct. Due to the hesitation performed by students in line 384 , the lecturer reformulates the question (line 387-389) using the key word 'exist'. After the students apprehend the concept, she changes into another subtopic 'vertical forces', again, by asking a question to the students (lines 391-393). The lecturer states that tripartite dialogue mediated by question is part of the lecture development and promote involvement which is important in science lecture. In addition, she wants to hear what the students feel and think, before moving to the next topics/sub-topics.

\begin{tabular}{|c|c|c|}
\hline \multicolumn{3}{|c|}{ Excerpt 4: LE (1) } \\
\hline 378 & 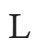 & No net force. $(/)$. when I say the \\
\hline 379 & & word no net force, does it mean \\
\hline 380 & & $\begin{array}{l}\text { there is or there is no force so ever? } \\
\text { (I) }\end{array}$ \\
\hline & $\mathrm{S}$ & (silence) \\
\hline 382 & $\mathrm{~L}$ & What is? What is the meaning of \\
\hline 383 & & no (I) net force? \\
\hline 384 & $\mathrm{~S}$ & (.8) (mumbles of no difference) \\
\hline 385 & $\mathrm{~L}$ & Are you sure they're just the same? \\
\hline 386 & 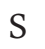 & (.3)(silence) \\
\hline
\end{tabular}

Excerpt 4: LE (1)

379 word no net force, does it mean

380 there is or there is no force so ever? (I)

381 S (silence)

$382 \mathrm{~L}$ What is? What is the meaning of

force?

385 L Are you sure they're just the same?

386 S (.3)(silence) 
387 L What do you know about no net

388 (/) force? They exist? or they

389 don't exist?

390 S (.5)They exist.

391 L What are (/)the forces::, the verti-

392 cal (I) forces:: that are on you

393 ri::ght:: now?

In a latter part of the lecture, the concept of contact is introduced to the students (line 421) at the beginning of the discussion, and to determine students' knowledge of it, a question-answer process (lines 421-423) is posed. In lines 425426 , the lecturer repeats the same question. Based on the response, it can be seen that the students have no idea about the concept (lines 424 and 427). Therefore, the lecturer latter elaborates it in a more simple way (428-429) using the tentative hedge 'like' and mentioning the physical contact as the key of learning contact (lines 435-438). The lecturer also provides the example of physical contact to elaborate further (lines 435-451). The lecturer realizes that sometimes the students give unclear or silent response, thus, she needs to confirm by asking and repeating questions. If she finds the students are still confused, she will explain the materials again. Please refer to Excerpt 5 below.

Excerpt 5: LE (1)

421 L Contact (.) Do you happen to know

422 about word contact? Contact (.) what

423 does it means?

$424 \mathrm{~S}$ (silence)

425 L How will you define contact? The defini-

426 tion of contact?

$427 \mathrm{~S}$ (inaudible response)
428 L Like, having a contact between two

429 things, two parties, right?

430 [points to two students and herself]

431 Currently, we are now having contact

432 hours, aren't we? (/) We are having

433 lectures, right? (/)

$434 \mathrm{~S}$ (no response)

$435 \mathrm{~L}$ What we are having now is a form of 436 contact hours. Ok, (/) it is mentioned 437 that contact ( ), includes (/) phy::sical 438 (/)contact, (..) that's the point (.) 439 physical contact (.) can you show me $440 \mathrm{~S}$ [student demonstrates something]

441 L Good. You are having contact, any442 thing else? Physical contact, over 443 there. [points towards students] (..) 444 No, no Sorry, not you. ((laughter)).

445 (.4) Okay (...) different illustrations of 446 physical contact, Keep in mind that as 447 long as we have, there is a touch be448 tween two things. Right? For instance, 449 the physical contact when the bottle is 450 put on the table and when you are 451 wearing your spectacles.

\section{Lecture 2}

In LE (2), the findings show that the lecturer combined display and referential questions from the beginning until the end of the lecture. To obtain students's knowledge on the topic, the lecturer employed not only 'wh' (what, who, where) or 'yes/no' questions (am I, does, are) and questions with modals (would, have, can), but also the intonation raising at the end of her sentences. She also performed code-switching in Malay and English.

To start the LE (2), the review of previous lecture is done by having questionanswer session with the students. The questions contain the topic of relative speed namely a stationary. In lines 20-22, the lecturer ask 'wh' question and choral response is given by the students (line 
23). Getting such response, she, then, poses two more 'yes/no' questions in lines 26-27 and 29, followed by a 'wh' question in line 31. Again, the students can answer the questions in lines 28, 30, and 32 . The questions posed by the lecturer are actually confirmation questions which function to check the students agreement toward statements that she delivers. They are also categorized as guiding questions which function to lead the students to understand some basic concepts in science step by step as she believes that the key for ease of understanding science is to understand concepts. This can be seen in Excerpt 6 .

\section{Excerpt 6: LE (2) \\ $18 \mathrm{~L}$ When driving a car. (hh) there is \\ 19 Another car coming to you. (...) \\ 20 Let say the car is stationary, what \\ 21 do we call the speed of the other car \\ $22 \quad$ which is coming to you? \\ $23 \mathrm{~S}$ (.7) our speed. \\ 24 L (.3) Okay. But cfrom the different \\ 25 diretion. \\ 26 Will you say that the tress are mov- \\ 27 ing while you are driving? \\ 28 S (.3) I will.:. \\ 29 L So, (/) the trees are actually moving? \\ 30 S No::: \\ 31 L Who does the movement? \\ 32 S We::}

After revisiting the previous learning materials, the lecturer announces the topic of the lecture using positive sentence, followed by an analogy and explanation. As can be seen in Excerpt 7 below, understanding 'center of mass' is mentioned to highlight the objective of the lecture. She makes a comparison by asking the students to imagine themselves as particles (line 225). After that, the lecturer moves around and finds the students are not doing the task correctly (line 230). Therefore, she nominates the students to illustrate and finishes with question (line 228). In line 229 the students give their response, showing their agreement, then, nominated students demonstrate to the class hilarity. In lines 234-236, the lecturer asks the volunteer students 'where is the centre of mass' and in lines 237238 , one student raises his hand, indicating he knows the answer. Here, she tries to explain what she has done, demonstration, as her teaching strategy that implies her concern toward the needs of her students. Similar to LE (1), this way of interaction is done as the lecturer believes that understanding concepts are paramount to physics and engineering. Understanding the concept is necessarily important before the students move on the calculation. This is also done as she wants the students get interested in the lecture.

\section{Excerpt 7: LE (2)}

218 L All students. Let's imagine:: every219 body becomes particle. [Pointing to 220 particular student] you don't like to 221 be particle, right (/)? I'm sureyou, 222 don't like it but yes you are, we are 223 doing this just to help the learning 224 easier and simpler to understand::. 225 [to the class] Others imagine to be 226 particle too.. The purpose is to under227 stand:: the centre of mass. (..) Every228 one, has a coordinate, right?

229 S Yes (.3)

230 L Alright, there are three particles. 231 [chooses to 3 students] ((laughter))

232 You can see this is very simple. Three 233 people are here (.) you're going to just 234 make a dot pattern (/) where is the 235 centre of mass Who becomes the centre 236 of mass? 
Once the topic has been introduced with analogy and brief explanation, the lecturer continues to topic development. In Excerpt 8, to know students' perspective toward the activity (finding coordinates), referential questions are asked to a group of students (lines 434-435, 440443 and 456-457). A student answers the questions (lines 436, 446-447, 449-451, 453-454, and 458-459. The lecturer says that during the lecture process, there should be an interaction between lecturer and students as the sharing of knowledge because the students' comments also part of the lecture development.

\section{Excerpt 8: LE (2)}

433 L Alright, now everybody has a coor-

434 dinate. Let's check, tell me what is

435 your coordinate?

$436 \mathrm{~S} \quad \mathrm{X} 5, \mathrm{y} 1$

437 L Wow, he is alrady on fire. (.5)

438 [laughter] X5, y: 1 . is it? So all of

439 you has your own coordinate, so

440 what are you going to do (/)? What

441 about this group, what is your ac-

442 tion(/)? Would you like to try? What

$443 \quad$ are you going to do(/)?

444 S (..) [inaudible response]

445 L Berdiri, bangun, bangun.

446 S We say each particle, (..) lets say $\mathrm{x}$

447 axis first

448 L Yes
S (..) times up the mass and the coordinate of $\mathrm{x}$ axis, (..) ignoring the $\mathrm{y}$ axis first so there is bar $\mathrm{x}$.

L Yes

S Okay, let's do over, (..)the other way round.

L Now as we can see (/), they are over there, not longer here. What are you saying?

S Mmm, but Mam, we got $\mathrm{x}$ coordinate already.

In another variation, Excerpt 8 shows the concept of conservation of momentum is introduced to the students through a question (lines 666-668). To encourage students to explain the meaning of conservation, the lecturer poses referential questions (lines 670-672) and codeswitching (lines 677-683, 685-686, and 690-692), she uses the conservation synonym. After that, she draws out the students' understanding of collision in relation to momentum, conservation of momentum, and the principle to find speed, followed by another referential question (lines 695-696). Here, the lecturer states that she attempts to negotiate meaning of concepts as well as provoke critical thinking skills of the students related to principle of sciences.

\section{Excerpt 9: LE (2)}

666 L Let me ask you this question. Are you familiar with conservation of momentum principle (/)_?

$\mathrm{S}$ Yes.

L What do you know about it (/)? How will you define conservation of momentum (/)?What does it mean?

$\mathrm{S} \quad(.7)$ [students give no response] 
683

684

685

686

687

688

689

690

691

692

693

694

695

696
$\mathrm{L}$ What does conservation of momentum mean(/)? (..) Ahh:: Apa makna conservation of momen::tum(/) ? (..) Apa makna conservation of momentum? (..) Is the English term becoming a problem for you (/) Atau apa ini? (..) Any idea? Apa makna conservation of momentum? The momentum does not? (.6)

S Change.::

L Good. Does not change. (.5) Apa makna does not change? Biasanya, when discussing about momentum what things are we talking about?

$S$ Collision

L Okay, Collision (/). Conservation of momentum:: maknanya (/) Before collision and (I)

S (.4) After:: collision::

L After collision. There are two objects moving and then collide. After that, what happens?

\section{Discussion}

This research investigated the use of questions, focusing on the types and function of questions, used by a science lecturer in university setting. From the findings, it can be seen that the lecturer developed the lecture through question-answer activities by frequently posing display, followed by referential questions. The questions were dominantly designed in 'wh' and 'yes/no'. There were also questions posed by using question tag and raising intonation at the end of utterances, signaling the students a clue to take turn and complete the utterance. Archer and Hughes (2011) and Shamossi (2004) agree that the use of a large quantity and variety of questions during the lectures is important to signal an interest of hearing what the students feel and think, indicat- ing an effort to encourage the students to get interested in the lecture, build interpersonal relations with the students, and promote involvement.

Interestingly, in some parts, the lecturer posed questions while switchingcode. She posed questions in English and repeated them in Bahasa Melayu. For example when she asked the students apa makna conservation of momentum?. Due to the fact that the majority of students in Malaysian university had experiences a Malay medium of instruction, the use of code-switching is not surprising. Rido and Sari (2018) claim that code-switching is a common scenario in a non-native environment with non-native teachers teaching and non-native students. The use of two languages can be used in certain situations like highlighting important points, clarifying meaning, and attracting the students' attention.

The findings also reveal that the questions posed by the lecturer were mostly responded by the students in short answers, except some referential-follow up questions which resulted in longer responses. In her study, Morell (2004, 2007) claims that the use of referential questions imporve the quality of students' responses. However, Tsui (1996) in Walsh (2011) claims that the implementation of referential questions does not always give impact toward longer and better learner responses. Meanwhile, follow-up question gets longer response as it signals an invitation for further discussion. Followup question also implies that the lecturer attempts to guide the students through the process of understanding which promotes negotiation of meaning and stimulates critical thinking skills (Olson \& 
Huckin, 1990; Shamossi, 2004).

Based on the interview results, the lecturer is eager to pose questions to the students for she tries to check the students' understanding toward the topic of lecture. She also wanted involvement, guided the students to understand the basic concept of science before moving on to the next concept, and raised students' critical thinking skills. It is important to emphasize the concepts because the key of learning science is undertanding concepts. Walsh (2011) asserts that lecturer can manage students' learning and contribution to the lecture by posing the questions. In addition, allocation of questions and nomination of students to answer questions give an apportunity for the students to voice their critical ideas. Questioning is found as effective means to identify students' difficulties because based on its nature, question requires response. Therefore, responses obtained from the questions let the students to engage in class discussion more actively, speak up their ideas, and learn from each other. which can lead to deep learning (Beaumont \& Chang, 2011; Fry, Ketteridge, \& Marshall, 2003; Walsh, 2011; Xuerong, 2012). However, bear in mind that even though students' participation in lecture process is highly reinforced, the lecturer's control toward the flow of the class is still needed.

\section{CONCLUSIONS}

To conclude, the lecturer employed a highly interactive style of lecture by posing a lot of questions in each lecture. She frequently used display and referential questions, with more display compared to referential and other types of questions in both lectures. The functions of questions were to help the lectures to be more interactive, strengthen lecturer and students' intrapersonal relations, and point the willingness to share discourse. Lecturer also can pose the questions to apprehend students' knowledge and understanding toward materials at hand.

The findings of this current research, to some extent, are in line with Morell (2004, 2007), Olson and Huckin (1990), and Brock (1986). What make this current research different from that of previous studies is that high frequency of a mixed up questions between display, referential and follow-up question is posed by the lecturer which she claimed invited more discussions and guided the students to understand concepts as the key to understand science. This developed critical as well as logical thinking skills of the students and contributed to the development of the lectures.

The findings of this research provide some implications and suggestions. The use of questions during the lectures promotes participation and guides the students to particular response. This study suggests that science lecturers should properly plan and manage the distribution of questions delivery to students in order to provide space and freedom in both what they say and when they say it. Science lecturers should also pose more open-referential questions to individual students as these provoke critical/logical thinking skills of the students and demonstrate higher level thinking order and involvement. 


\section{ACKNOWLEDGMENTS}

The researcher is grateful to the Centre for Research and Community Services Universitas Teknokrat Indonesia for granting the research fund.

\section{REFERENCES}

Archer, A.L., \& Hughes, C.A. (2011). Explicit instruction: Effective and efficient teachng. London: The Guilford Press.

Athanasiadou, A. (1991). The discourse function of questions. Pragmatics: Quarterly Publication of the International Pragmatics Association 1 (Mar): 107-122. https://journals.linguisticsociety.org/elanguage/pragmatics/ article/download/332/332-618-1PB.pdf.

Beaumont, M. \& Chang, K. S. (2011). Challenging the traditional/communicative dichotomy. ELT Journal, 65(3): 291-299. https://doi. org/10.1093/elt/ccq091.

Brock, C. (1986). The effects of referential questions on ESL classroom discourse. TESOL Quarterly 23(3): 421$445 . \quad$ https://doi. org/10.2307/3586388.

Camiciottoli, Crawford B. (2004). Interactive discourse structuring in L2 guest lectures: some insights from a comparative corpus-based study. Journal of English for Academic Purposes 3: 39-54. https://doi. org/10.1016/S1475-1585(03)000444.

Creswell, J. W. (2007). Qualitative inquiry and research design: Choosing among five approaches ( $2^{\text {nd }}$ ed.). CA: Thousand Oaks.
Curtis, B. \& Curtis, C, (2013). Social research, a practice introduction. London: Sage Publications.

Di Grapello, E. (2013). Role of education and training sector in addressing skill mismatch in Indonesia. In Suryadharma, Daniel \& Jones, Gavin. W (Eds.). Education in Indonesia (pp. 236-266). Singapore: Institute of Southeast Asian Studies.

Di Grapello, E., Kruse, A., \& Tandon, P. (2011). Skills for the labor market: Trends in demands, gaps, and supply. Washington DC, USA: World Bank.

Dufon, M.A. (2002). Video-recording in ethnographic SLA research: some issues of validity in data collection. Language Learning and Technology, 6(1): 40-59. https://doi.org/ $10125 / 25142$.

Fry, H., Ketteridge, S., \& Marshall, S. (2003). A handbook of teaching and learning in higher education (second edition). London: British Library Catalogue.

Flowerdew, J. (2002). Ethnographically inspired approaches to the study of academic discourse. In Flowerdew, J (Ed.). Academic discourse. London: Pearson Education Limited. pp. 233252.

Fontana, A. \& Frey, J. H. (2000). The interview: from structured questions to negotiated text. In Denzin, Norman K., and Lincoln, Yvonna S (Eds.) Handbook of qualitative research, $2^{\text {nd }}$ ed. Thousand Okas, CA: Sage. pp. 645-672.

Freihat, S. \& Al-Machzoomi, K. (2012). The picture of workplace oral com- 
munication skills for ESP Jordanian business graduate employees. International Journal of Business, Humanities and Technology. 2 (1), 159-173. http://www.ijbhtnet.com/journal/ index/106.

Hendarman. (2010). Incorporation of employability skills in teachinglearning process within TVE schools. Proceedings of $1^{\text {st }}$ UPI International Conference on Technical and Vocational Education (pp. 301-309). Bandung: Universitas Pendidikan Indonesia.

Ihmeideh, F.M., Al-Omari, A.A., \& AlDababneh, K.A. (2010). Attitudes toward communication skills among students'-teachers in Jordan public universities. Australian Journal of Teacher Education. 35 (4), 1-11. https://files.eric.ed.gov/fulltext/ EJ910389.pdf.

Jefferson, G. (2004). Glossary of transcript with an introduction. In G.H. Lerner (Ed.). Conversation analysis: Studies from the first generation (pp. 1331). Amsterdam: John Benjamin.

Morell, T. (2007). What enhances ELS students' participation in lecture discourse? Student, lecturer and discourse perspective. Journal of English for Academic Purposes 6: 222-237. https://doi.org/10.1016/j. jeap.2007.07.002.

Morell, T. (2004). Interactive lecture discourse for university ELF students. English for Specific Purposes 23(3): 325-338. https://doi.org/10.1016/ S0889-4906(03)00029-2.

North, A.B. \& Worth, W.E. (2004). Trends in selected entry-level tech- nology, interpersonal, and basic communication SCAN skills: 19922002. Journal of Employment Counseling. 41. 60-70. https://doi. org/10.1002/j.2161-1920.2004. tb00879.x.

Olson, L.A. \& Huckin, T.N. (1990). Point-driven understanding in engineering lecture comprehension. English for Specific Purposes, 9, 33-47. https://doi.org/10.1016/08894906(90)90027-A.

Perakyla, A. \& Ruusuvuori, J. (2013). Analyzing talk and text. In Denzin, Norman K \& Lincoln, Yvonna S (Eds.). Collecting and interpreting qualitative materials (pp. 277-308). Los Angeles: Sage Publications.

Rido, Akhyar \& Sari, Fatimah Mulya. (2018). Characteristics of classroom interaction of English in language teachers in Indonesia and Malaysia. International Journal of Language Education, 2(1): 40-50. http://dx.doi. org/10.26858/ijole.v2i1.5246.

Riemer, M.J. (2007). Communication skills for the $21^{\text {st }}$ century engineer. Global Journal of Engineering Education, 11(1): 89-100. http://www.wiete.com.au/journals/GJEE/Publish/TOCVol11No1.html.

Shamossi, N. (2004). The effect of teachers' questioning behavior on EFL classroom interaction: a classroom research study. Reading Matrix, 4(2): 96-104. http://www.readingmatrix. com/archives/archives_vo14_no2. html.

Simpson, R.C., Lee, D.Y.W., \& Leicher, S. (2002). MICASE manual. Ann 
Abor, MI: English Language Institute, The University of Michigan.

Walsh, Steve. (2011). Exploring classroom discourse: Language in action. London: Routledge.

Wong, J. \& Waring, H.Z. (2010). Conversation analysis and second language pedagogy. New York: Routledge.
Xuerong Fan. (2012). Excellent English teachers' classroom strategies: A case study of three college English teacher in China. Higher Education Social Sciences. 2(1), 1-7. https://doi. o r g / 10 . 3968 / j . hess.1927024020120201.2115. 